\title{
Use of Siam weed biomarker in assessing heavy metal contaminations in traffic and solid waste polluted areas
}

\author{
${ }^{1 *}$ F. O. Agunbiade; ${ }^{2}$ A. T. Fawale \\ ${ }^{1}$ Department of Chemical Sciences, College of Natural and Applied Science, Bells University of Technology, \\ Ota, Nigeria
}

${ }^{2}$ International Institute of Tropical Agriculture, Ibadan and presently is a Production Operator with Chevron Nigeria Ltd, Chevron Nigeria/Mid-Africa SBU

Received 8 August 2008; $\quad$ revised 29 December 2008; accepted 22 January 2009; $\quad$ available online 1 March 2009

\begin{abstract}
The ability of Chromolaena odorata to accumulate and serve as biomarker to lead and cadmium metals pollution load had been revealed by this study. Samples of soils and Siam weed were collected to assess impacts of solid waste disposal and traffic density on the environment. Composite sample were collected from a solid waste dumpsite, three traffic polluted areas with varying traffic density and a background site distant from traffic. Concentration of eight elements: cadmium, cobalt, chromium, copper, iron, nickel, lead and zinc were determined in soil and plant samples and correlated together. Accumulative factors like pollution load index, transfer factor, contamination factor, enrichment factor were calculated for the metals in both plants and soils and used as basis for interpreting the state of the environment and ability of $C$. odorata to accumulate metals. The accumulative factors of plants were generally greater than that of soil samples indicating increased accumulative capacity of the plant. The accumulations of lead and cadmium in C. odorata were remarkable with contamination factor 10.51 and 23.50 , respectively and mean enrichment factors 3.52 and 6.93, respectively. Other metals had lower accumulative factors. The distribution of metals and calculated factors placed solid waste disposal site as the most polluted site while the trend observed in areas with traffic pollution depicts the ability of $C$. odorata to clean up metal pollution by accumulating them. It can therefore be suggested that solid waste disposal negatively affects the environment more than traffic pollution subject to the volume of traffic.
\end{abstract}

Keywords: Chromolaena odorata, soil, waste disposal, contamination factor, metals pollution

\section{INTRODUCTION}

The ability of living tissues to accumulate, magnify and transform pollutants in the environment has made them of great significance in environmental studies. Plant and animal tissues have been reported to be capable of accumulating and magnifying trace pollutants like heavy metals and organic micropollutants to a level that is very toxic to lives (Cabrera, et al., 2006; Gonzalez and Gonzalez-Chavez, 2006; Liu et al., 2005; Madejon et al., 2006). Thus, up in the food web, such pollutants that exist in trace levels and are seen as normal become issues of great concern. Likewise, mercury $(\mathrm{Hg})$ in metallic or inorganic form is not toxic, but could be biotransformed through biochemical reactions in living tissues into highly toxic organic form (methylmercury) which cause great damage to terrestrial and aquatic lives and the \*Corresponding Author Email: foagunbiade@gmail.com Tel./Fax: +2348 055136498 ecosystem. Therefore, the assessment of pollutants in soils, water and sediments is not enough an indication of the state of the environment without a serious consideration of such pollutants in the tissues of living organisms that are part of the food web and importantly the assessment of bioavailability of the pollutants in living tissues which is the strong indication of their toxicity (Farkas et al., 2002; Vutukuru, 2005; Waqar, 2006). Moreover, pollutants are continually introduced into the environment from several human sources which include industrial, commercial and domestic activities (Cao and Hu, 2000; Conacher et al., 1993; Fang et al., 2006; Velez and Montoro, 1998; Wang et al., 2003). Waste products generated from these activities compromise the state of the environment. The conservation of the environment and human/industrial development are therefore two conflicting issues that continues to generate debate among researchers and 
policymakers. Hence, the ability of the environment to absorb pollutants or cleanup itself by natural biological/ biochemical activities have become the focus of scientific research so that to shift from chemical remediation to bioremediation where biota are used to accumulate or absorb and remove contaminants from the environment (Gardea-Torresdey et al., 1997; Hammaini, et al., 2006). Thus, plants, plankton and other biota are increasingly being used to evaluate metal pollution as biomarker and even to remedy the environment. Therefore, investigation on the use of Chromolaena odorata (Siam weed) for this purpose was done. Siam weed is a widely dispersed neotropical shrub introduced to many parts of the tropics (Cruttwell McFadyen, 1988). It occurs in disturbed areas, grasslands, fallow and forestry plantations. It has efficient short and long distance dispersal abilities. The plant is originated from the Caribbean, but has invasive population in Asia, southern and western Africa (Cruttwell McFadyen and Skarrat, 1996). It was accidentally introduced with forestry seed in Nigeria in 1947 (Ivens, 1974). It is a very resilient plant that survives cases of fire, drought or mechanical damage through coppicing because of an underground organ it possessed thereby tolerating a variety of climates (Gautier, 1993). Over 240 arthropods have been reported on C. odorata in Trinidad and it has been investigated for detailed potential in biocontrol of pests and diseases (Binggeli, 1997). This plant is a problem in agricultural land and commercial plantations, but its ability to serve as a biomarker and bioremediation agent needs investigation. Therefore, the present study investigates the use of $C$. odorata as a biomarker of metal polluted soils from traffic polluted and solid waste dump sites. The study was conducted in Ibadan, Nigeria in January - March 2002.

\section{Experimental design}

The experimental design of the study involved sampling from test sites and a control site. The control site is a location distant from traffic and other anthropogenic source of metal contamination. Chemical analysis was done using standard methods and statistical analysis using correlation technique and Dunnett parametric multiple comparison was carried out on data to compare between test sites and the control site.

\section{Sampling strategy}

Composite, random soil samples were collected from five locations in Ibadan, Nigeria latitude at $7^{\circ} 15^{\prime}$ to $7^{\circ}$
30 ' and longitude at $3^{\circ} 45^{\prime}$ to $4^{\circ} 00^{\prime}$ (Fig. 1). The soil samples were collected at the surface and bottom (25 $\mathrm{cm}$ ) randomly across each site. All the samples, were analysed for the following metals: $\mathrm{Cu}, \mathrm{Cd}, \mathrm{Cr}, \mathrm{Co}, \mathrm{Fe}$, $\mathrm{Pb}, \mathrm{Ni}, \mathrm{Zn}$. This was done in three different locations in each sampling site to obtain three replicate samples and the analysis was done in duplicate. The choice of test sites was based on traffic density and closeness to solid waste dumpsite. Site $\mathrm{E}$ is a solid waste dumpsite while sites B - D were close to traffic. Site B has traffic density above 1000 vehicles/h while site $C$ has between 300 and 1000 vehicular movement per h. Site D has less than 300 vehicles/h traffic density. A background site (site A) was selected at the remote part of the city far from industrial, commercial, and domestic activities. The C. odorata was identified at the Department of Botany, University of Ibadan and samples of this plant were collected at each spot from which, soils were collected as stated above to establish correlation between the two criterions. Three replicate plant samples per site were obtained and eventually analysed for the identified heavy metals in duplicate.

\section{Chemical analysis}

Plant samples were oven dried at $75^{\circ} \mathrm{C}$ for $48 \mathrm{~h}$ and then grounded into fine powder using a hammer mill. Finely ground plant materials weighing $250 \mathrm{mg}$ were digested with $5 \mathrm{~mL}$ concentrated nitric acid (analar grade). The digests were diluted to $50 \mathrm{~mL}$ using demineralized-distilled water. Soil samples were airdried and then sieved through a $0.5 \mathrm{~mm}$ sieve. Soil weighing $0.5 \mathrm{~g}$ from each dried sample was digested with $10 \mathrm{~mL}$ aqua regia, for $1 \mathrm{~h}$ and then $5 \mathrm{~mL}$ perchloric acid was added and digestion further for about $4 \mathrm{~h}$ in a reflux system until the soil became grey and the digest made up to $50 \mathrm{~mL}$. All samples were then analysed for $\mathrm{Co}, \mathrm{Cd}, \mathrm{Cr}, \mathrm{Cu}, \mathrm{Fe}, \mathrm{Ni}, \mathrm{Zn}$ and $\mathrm{Pb}$ metal ions using a flame atomic absorption spectrometer (AAS) Buck scientific 205 model with direct air-acetylene flame method. All used reagents were analytical grade and all used glassware were washed in metal free detergent and soaked in nitric acid after which it was washed in demineralised-distilled water. Samples blanks analysis were done to correct for external contributions while standards from National Institute of Standard and Technology (USA) were obtained and subjected to the same analytical process to evaluate recovery, accuracy and ensure quality control of the method. The recovery of the metals ranged from $94-102 \%$. 


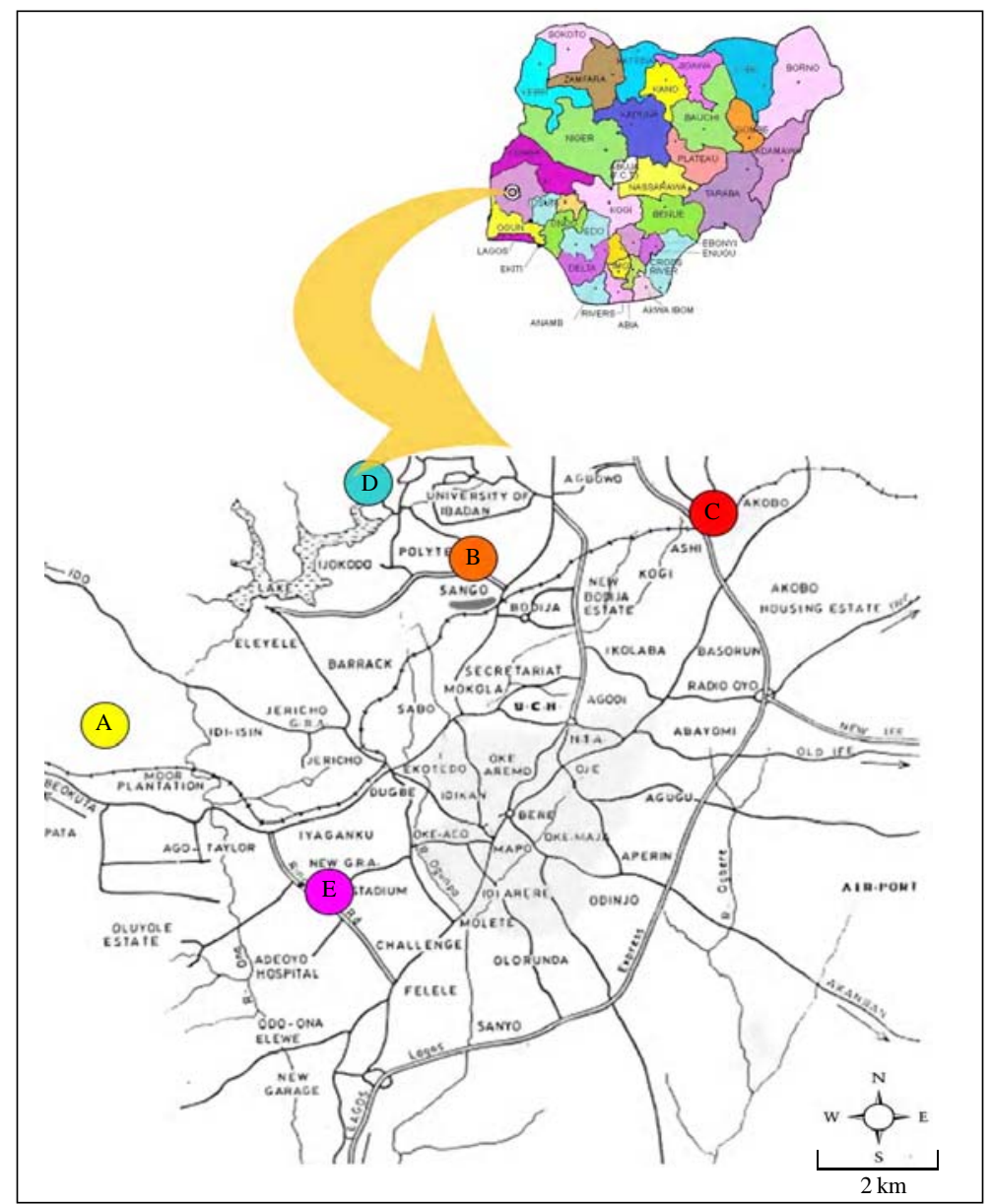

Fig. 1: Map of sampling location representing sampling points (Site A: Background; Site B: Traffic density above 1000 vehicles/h; Site C: 300-1000 vehicles/h; Site D: Less than 300 vehicles/h; Site E: Solid waste dumpsite

\section{Data analysis}

The mean values of the raw data generated from the chemical analysis were plotted to express comparative concentration of metals in soil and plant with variations across sites. The error bars on the plots were standard error of mean obtained from three replicate samples analysed in duplicate. The standard error was calculated at $95 \%$ confidence limit with a sample size, $n=6$. Dunnett parametric multiple comparison (Dunnett, 1955) was carried out between the test sites and the control site which reveals a significant difference between the test sites and control site at $95 \%$ confidence limit. A correlation model was made to establish relationship between the metals in the soil for each site and that of the plant from same site. The transfer or bioconcentration factor (TF or BCF) of the metal into the plant was also determined using the expression $\mathrm{C}_{\mathrm{p}} / \mathrm{C}_{\mathrm{s}}$ where, $\mathrm{C}_{\mathrm{p}}$ is concentration of the metal in plant and $\mathrm{C}_{\mathrm{s}}$ is the concentration of the metal in corresponding soil. TF greater than 1 indicates high level of accumulation of metals in the plant. Other determined factors were enrichment factor, pollution load index and contamination factor. Enrichment factors (EF) of the metals in the soils and plants were calculated for each metal relative to the background concentration obtained from a site (site A) free from traffic, industrial and solid waste pollution. The expression used for EF determination was that reported by Liu et al. (2005):

E. F. $=\frac{\frac{C_{n} \text { (sample) }}{\left.C_{\text {ref }} \text { (sample }\right)}}{\frac{\left.B_{n} \text { (background }\right)}{\left.B_{\text {ref }} \text { (background }\right)}}$ 
Where, $\mathrm{C}_{\mathrm{n}}$ (sample) is the concentration of metals in sample, $C_{\text {ref }}$ (sample) is the reference metal's concentration in sample and $\mathrm{B}_{\mathrm{n}}$ (background) is the concentration of the metals in background environment and $B_{\text {ref }}$ (background) is the reference metal's concentration in background environment. The reference metals that have been widely used in literatures were $\mathrm{Mn}, \mathrm{Al}$, Ti, Sc and Fe (Fang et al., 2006; Liu et al., 2005; Quevauviller et al., 1989; Reinmann et al., 2000; Schiff and Weisberg, 1999). For instance, Fe was used as the reference metal in this study because it was found most abundant in the soil and plant, implying that its occurrence within the experimental sites is natural. Enrichment factor with values lower than 2 indicates deficiency of mineral enrichment while EF between 2 and 5 demonstrates moderately enriched samples. Any EF value of above 5 is significantly highly enriched. Furthermore, to evaluate the severity of pollution of the soils and plants, the pollution load index (PLI) defined by Tomlison et al. (1980) was evaluated with the expression:

$$
P L I=\left[\pi^{n} i\left(c_{f i}\right)\right]^{1 / n}
$$

Where, $\mathrm{C}_{\mathrm{fi}}$ is the concentration factor of each metal obtained by the ratio of concentration of each metal in soil or plant to that of the metal in baseline soil or plant; $\pi$ is the geometrical mean operator; $n$ is the number of metals investigated and $i$ is each metal. When PLI value is below or close to one, it indicates heavy metal loads at the baseline, while values above one indicate heavy metal accumulation or pollution in plant or soil from the test site. The contamination factor (CF) has been used to assess soil contamination (Hakanson, 1980) through comparison of the concentrations in the surface layer to background values by the expression:

$$
c_{f}^{i}=\frac{c_{0-1}^{i}}{c_{n}^{i}}
$$

Where, $C_{f}^{i}$ is the contamination factor (CF), $C_{0-1}^{i}$ is the mean of the concentrations of individual metal from all test sites and $C^{i}{ }_{n}$ is the baseline or background concentration of the individual metal. The concentration of elements was used at site $\mathrm{A}$ as the baseline concentration. This expression was also adopted to calculate CF in plant samples. CF was defined according to four categories as follows:

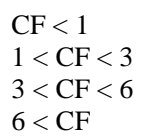

- Low contamination factor

- Moderate contamination factor

- Considerable contamination factos

- Very high contamination factor

\section{RESULTS AND DISCUSSION}

Evaluation of metal contamination in soil and plant samples

The comparative representation of concentrations of heavy metals investigated in soil and plant samples is presented in Fig. 2a-h. Generally, the concentrations of the metals in soil were more than that of the plant. The relative abundance of the metals measured by their mean concentration in the soil was found to be in the order of $\mathrm{Fe}>\mathrm{Cu}>\mathrm{Zn}>\mathrm{Cr}>\mathrm{Co}>\mathrm{Pb}>\mathrm{Ni}>\mathrm{Cd}$ while that of plant samples was $\mathrm{Fe}>\mathrm{Zn}>\mathrm{Cu}>\mathrm{Pb}>\mathrm{Ni}$ $>\mathrm{Co}>\mathrm{Cr}>\mathrm{Cd}$. The shift in the relative abundance position of $\mathrm{Pb}$ and $\mathrm{Ni}$ was notable in plant indicating a possibility of accumulation of these two metals in the plants in comparison to $\mathrm{Cr}$ and $\mathrm{Co}$. Concentration of the metals in the soil samples from the background site were generally low except for $\mathrm{Cu}$ which had the highest concentration among the studied metals and these background site metal concentrations were significantly different from the test sites at $95 \%$ confidence limit when tested with Dunnett parametric multiple comparison. Comparatively, $\mathrm{Cr}$ and Fe ranked midway to the other metal concentrations, but were lower than their respective mean concentrations. In plant samples, concentrations of metal were the lowest for the samples collected at the background site except for Ni. This indicated that the background site was less stressed by environmental contaminations and was suitable for use as a control or reference site. The consideration of the enrichment factor (EF) and the pollution load index (PLI) gives a better picture of the trend of metal contamination per site for both the plant and the soil.

\section{Site distribution and enrichment of heavy metals in soils and plants}

The trends of various metal concentration observed per sampling site showed that site B with vehicular density of over 1000 vehicles/h had a lower concentration of $\mathrm{Pb}, \mathrm{Zn}, \mathrm{Co}$, Ni and $\mathrm{Cu}$ than site $\mathrm{C}$ with density of $300-1000$ vehicles/h. Similarly, site C had lower concentration of $\mathrm{Pb}, \mathrm{Cr}$, Co and Fe than site $\mathrm{D}$. However, concentrations of some of these metals in the plants were higher in samples from site B, especially $\mathrm{Pb}$ and $\mathrm{Cu}$ which indicated a possibility of $C$. odorata 

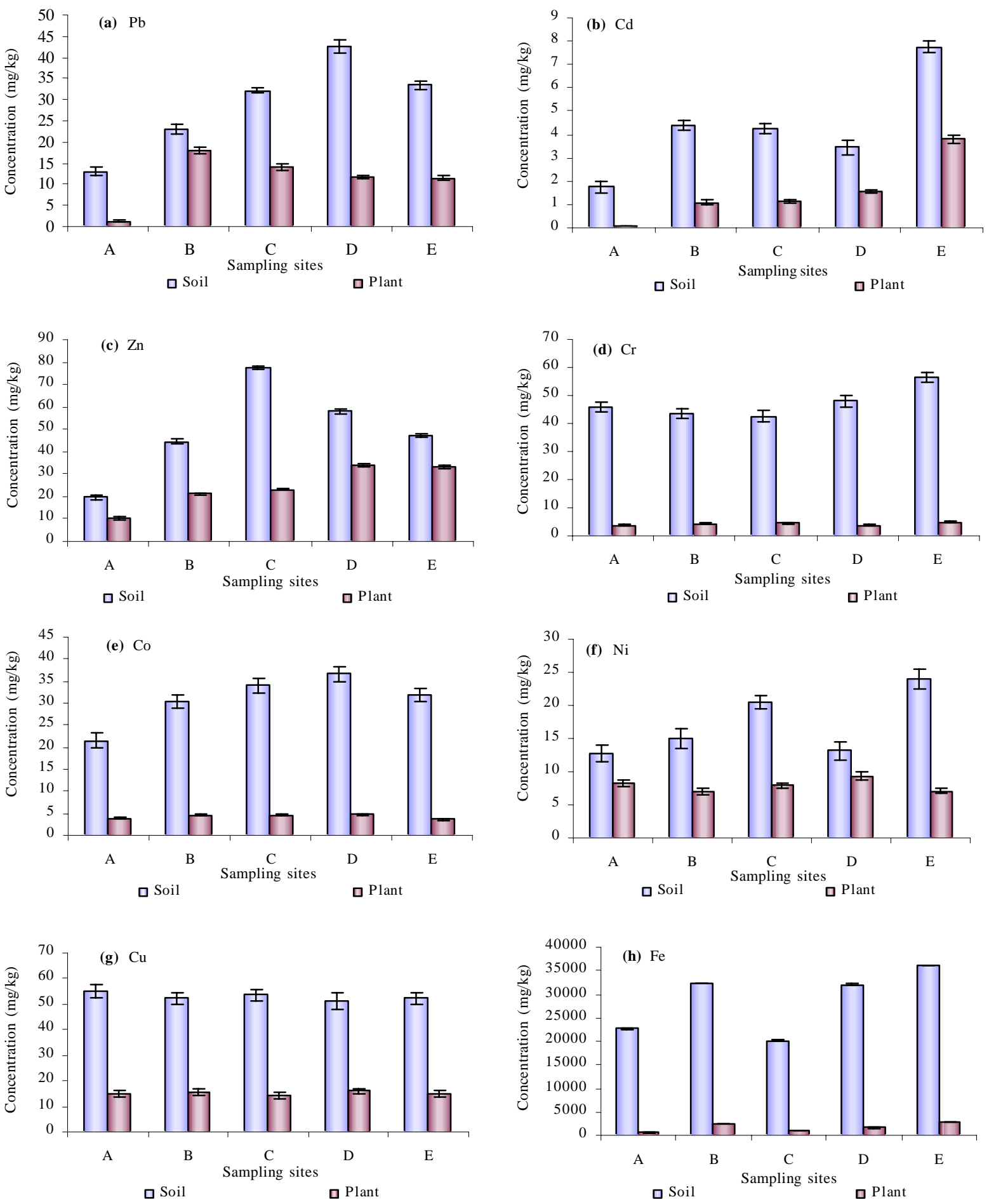

Fig. 2: Comparative graphs of the mean concentrations of 8 heavy metals in soil and plant samples collected from 5 sites. Site A: Background site; Site B: Traffic density above 1000 vehicles/h; Site C: 300-1000 vehicles/h; Site D: Less than 300 vehicles/h; Site E: Solid waste dumpsite 


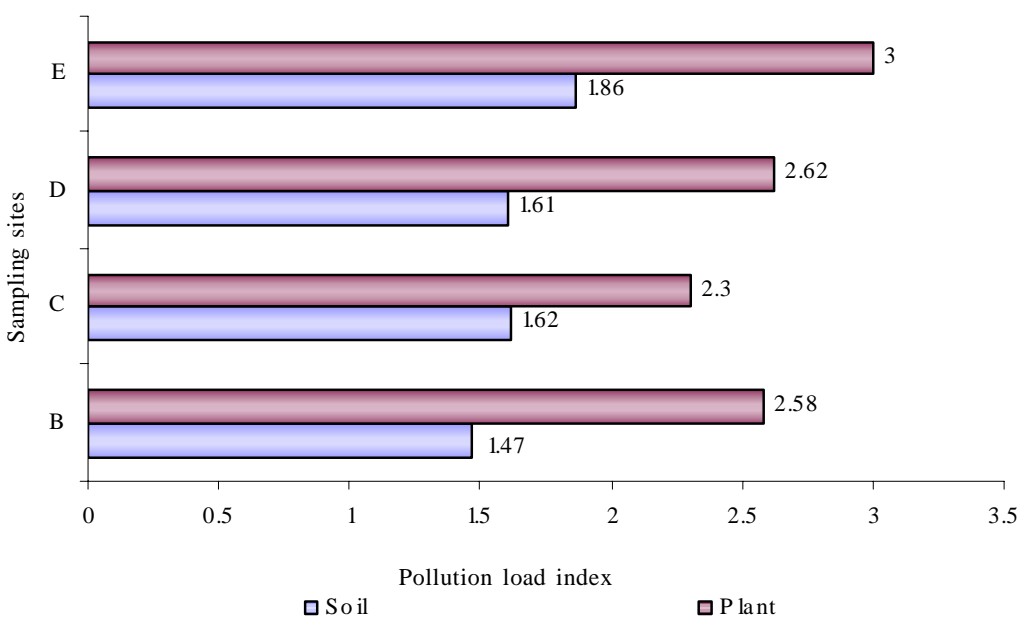

Fig. 3: Graph of pollution load index of soil and plant. Site B: Traffic density above 1000 vehicles/h; Site C: $300-1000$ vehicles/ h; Site D: Less than 300 vehicles/h; Site E: Solid waste dumpsite

cleaning up (i. e. by remediation) these metals from the soil through bioaccumulation (Cao and $\mathrm{Hu}, 2000$; Cui et al., 2004; Gonza'lez and Gonza'lez-Cha'vez, 2006; Tsui et al., 2006). The EFs (Table 2) showed the soil samples from site B to be less enriched. The extent of enrichment measured as their mean values gives a trend of site $\mathrm{C}>$ site $\mathrm{E}>$ site $\mathrm{D}>$ site $\mathrm{B}$. However, site $\mathrm{B}$ and $\mathrm{E}$ were expected to be much enriched because of the level of pollutant source(s) associated with them. This trend of result was further established by the PLI (Fig. 3) of the soil samples which ranked the severity of pollution in the soil as site $\mathrm{E}>$ site $\mathrm{C}>$ site $\mathrm{D}>$ site $\mathrm{B}$. Thus, site $\mathrm{E}$ was found to be the most stressed by metal pollutants, implying that metal pollution from solid wastes disposal is more significant than that from vehicular traffic. Unexpectedly, site B was the least polluted especially relative to other sites polluted by vehicular movement. Site $\mathrm{C}$ and $\mathrm{D}$ were expected to be less polluted than site $\mathrm{B}$ (especially with $\mathrm{Pb}$, which is emitted from exhaust of gasoline engines), but the trend was not significant. This observed trend and the comparative values of PLI of soil to that of the plant (Fig. 3) revealed the potential of $C$. odorata in cleaning up metal contamination and to act as biomarker of metal pollution and accumulation. Alfalfa (Medicago sutivu L.) has been reported in literature to show similar ability of extreme resistant to high levels of contaminants, as well as to serve as bioaccumulator (Gardea-Torresdey et al., 1997), while water spinach is reported to have the potential to accumulate $\mathrm{Hg}$,
Pb and Cd (Gothberg et al., 2004). The PLI (Fig. 3) of plant samples revealed that there was higher accumulation of metal pollutant in site $\mathrm{B}$ and $\mathrm{D}$ relative to $C$, thereby making the metal's accumulation in the soil samples lower than that of site C. The severity of pollution in plant were thus ranked as site $\mathrm{E}>$ site $\mathrm{D}$ $>$ site $\mathrm{B}>$ site $\mathrm{C}$. Therefore, the plants in site B and D accumulate the metals in the soils from the sites and reduced metal concentration and pollution load in soils explaining why they were relatively lower than other sites. Likewise, the mean transfer factors (TFs; Table 1) which depict the rate of transfer or bioconcentration of metals from soil to plant shows higher transfer values of metals in site D than site B and E. However, site $C$ and $A$ had the least metal transfer to plant (from soil) which further explains the trend observed and support the view that $C$. odorata is capable of reducing metal load in soil by accumulation in the former. The pollution severity of site $\mathrm{E}$ ranked the highest among all the sites in both soil and plant indicating further that pollution from solid wastes disposal is more significant than atmospheric precipitation from traffic or vehicular activities. Overall, comparison of all PLI values of plant samples with that of the soil samples depicted a more severe pollution in the plants, further establishing that the plant had the potential to accumulate and magnify metal pollutants and serve as a good tool in evaluating pollution severity and as a bioremediation agent. This is comparable with the results of metal accumulation reported in literature (Farombi et al., 2007; Gillis et al., 2004). 
Int. J. Environ. Sci. Tech., 6 (2), 267-276, Spring 2009

Table 1: Transfer or bioconcentration factor of metals from soil to plant

\begin{tabular}{lccccccccc}
\hline Site & $\mathrm{Pb}$ & $\mathrm{Cd}$ & $\mathrm{Zn}$ & $\mathrm{Cr}$ & $\mathrm{Co}$ & $\mathrm{Ni}$ & $\mathrm{Cu}$ & $\mathrm{Fe}$ & $\mathrm{Mean}$ \\
\hline $\mathrm{A}$ & 0.10 & 0.03 & 0.54 & 0.08 & 0.18 & 0.65 & 0.27 & 0.03 & 0.24 \\
$\mathrm{~B}$ & 0.78 & 0.03 & 0.47 & 0.10 & 0.15 & 0.46 & 0.30 & 0.08 & 0.30 \\
$\mathrm{C}$ & 0.44 & 0.27 & 0.30 & 0.11 & 0.14 & 0.39 & 0.27 & 0.05 & 0.25 \\
$\mathrm{D}$ & 0.27 & 0.44 & 0.58 & 0.08 & 0.13 & 0.71 & 0.31 & 0.05 & 0.32 \\
E & 0.34 & 0.49 & 0.70 & 0.09 & 0.11 & 0.29 & 0.29 & 0.08 & 0.30 \\
Mean & 0.39 & 0.25 & 0.52 & 0.09 & 0.14 & 0.50 & 0.29 & 0.06 \\
\hline
\end{tabular}

Table 2: Enrichment factor of metals in soil per sampling point

\begin{tabular}{lccclllll}
\hline Site & $\mathrm{Pb}$ & $\mathrm{Cd}$ & $\mathrm{Zn}$ & $\mathrm{Cr}$ & $\mathrm{Co}$ & $\mathrm{Ni}$ & $\mathrm{Cu}$ & $\mathrm{Mean}$ \\
\hline $\mathrm{B}$ & 1.24 & 1.76 & 1.59 & 0.66 & 1.00 & 0.83 & 0.67 & 1.11 \\
$\mathrm{C}$ & 2.80 & 2.73 & 4.48 & 1.04 & 1.79 & 1.81 & 1.10 \\
$\mathrm{D}$ & 2.32 & 1.39 & 2.10 & 0.74 & 1.20 & 0.73 & 0.66 \\
$\mathrm{E}$ & 1.62 & 2.77 & 1.51 & 0.77 & 0.93 & 1.18 & 0.60 & 1.31 \\
Mean & 2.00 & 2.16 & 2.42 & 0.80 & 1.23 & 1.14 & 0.76 & 1.34 \\
\hline
\end{tabular}

Assessment of individual metal contaminant and transfer factor

Moreover, a comparison between degrees of enrichment of metals in soil based on the average of their EFs (Table 2) placed Zn as the most enriched metal in soil samples followed by $\mathrm{Cd}$ and $\mathrm{Pb}$. The soil samples had deficiency of other metals. The enrichment of the soil with $\mathrm{Zn}$ is not of much concern for being a beneficial metal (at micro level) to plants and animals. However, $\mathrm{Cd}$ and $\mathrm{Pb}$ are of serious concern and adequate control of their sources is paramount because of their negative impact on biotics and the ecosystem at large. $\mathrm{Pb}$ and Cd affect metallothionein, a cystine rich, low-molecularweight, metal-binding protein (Perceval et al., 2002) and hormonal activity in living organisms (Laflamme $e t$ al., 2000). Pb has caused anaemia, brain damage, anorexia, renal failure, mental deficiency, vomiting and even death in human (Bulut and Baysal, 2006; Low et al., 2001) even at trace levels lower than the observed concentration in this study. Cd also has been reported to cause bone disease, agonistic and antagonistic effects on hormones and enzymes leading to lots of malformations (Manahan, 1992). Renal damage resulting in proteinuria has been caused by $\mathrm{Cd}$ through its adverse effect on the enzyme responsible for the readsorption of protein in the kidney tubules (Donalson, 1980). These two metals have affinity for SH groups in proteins, haemoglobin, enzymes/hormones thus affecting their activities (Manahan, 1992). Cd had been reported to be easily absorbed by plants (Sheng et al., 2001; Wang, 2001). This aspect was proved in this study, by the observed mean EF and $\mathrm{CF}$ of $\mathrm{Cd}$ in $C$. odorata being noticeably the highest i. e. 6.93 (Table
3) and 23.5 (Fig. 5), respectively. The EFs of plant samples (Table 3) create a clear picture of the capacity (3.52 and 6.93) of $C$. odorata for accumulation of $\mathrm{Pb}$ and Cd metals.

In addition, the correlation of metals analysed from soil and plant (Table 4) showed a strong positive relationship and association (0.96 and 0.89 ) between $\mathrm{Cd}$ and $\mathrm{Fe}$ in the two environmental media. However, $\mathrm{Pb}, \mathrm{Zn}, \mathrm{Cr}$ and $\mathrm{Co}$ exhibited a moderate relation in the case, but there is a negative association between $\mathrm{Cu}$ and $\mathrm{Ni}$ from the two sources. It is therefore clearly demonstrated that $\mathrm{Cd}$ and $\mathrm{Fe}$ in plants were sourced by transfer from soil while $\mathrm{Pb}, \mathrm{Zn}, \mathrm{Cr}$ and $\mathrm{Cu}$ are contributed from other additional sources like atmospheric precipitation in addition to the contribution from the soil. Furthermore, the evaluation of TF for each metal with its mean values presented in Table 1 indicates the order of transfer of metals in decreasing order as $\mathrm{Zn}>\mathrm{Ni}>\mathrm{Pb}>\mathrm{Cu}>\mathrm{Cd}>\mathrm{Co}>\mathrm{Cr}>$ Fe. Similarly, TF values places $\mathrm{Zn}$ as the most transferred metal followed by Ni while the third position occupied by $\mathrm{Pb}$ raise concern though the TFs were generally less than 1. Finally, the contamination factor of metals in soil (Fig. 4) and plant samples (Fig. 5) confirmed that $\mathrm{Zn}$ is the highest contaminant in soil followed by $\mathrm{Cd}$ and $\mathrm{Pb}$ in that order while $\mathrm{Cd}$ and $\mathrm{Pb}$ contamination in plant samples were remarkably too high relative to other metals. This further revealed the potential use of $C$. odorata as a biomarker and for cleanup of these pollutant metals from the environment. The contamination factors of other metals in plant and soil samples were however quite moderate at less than 3 except for $\mathrm{Fe}$ in plant that was considerably high at 3.49 . 


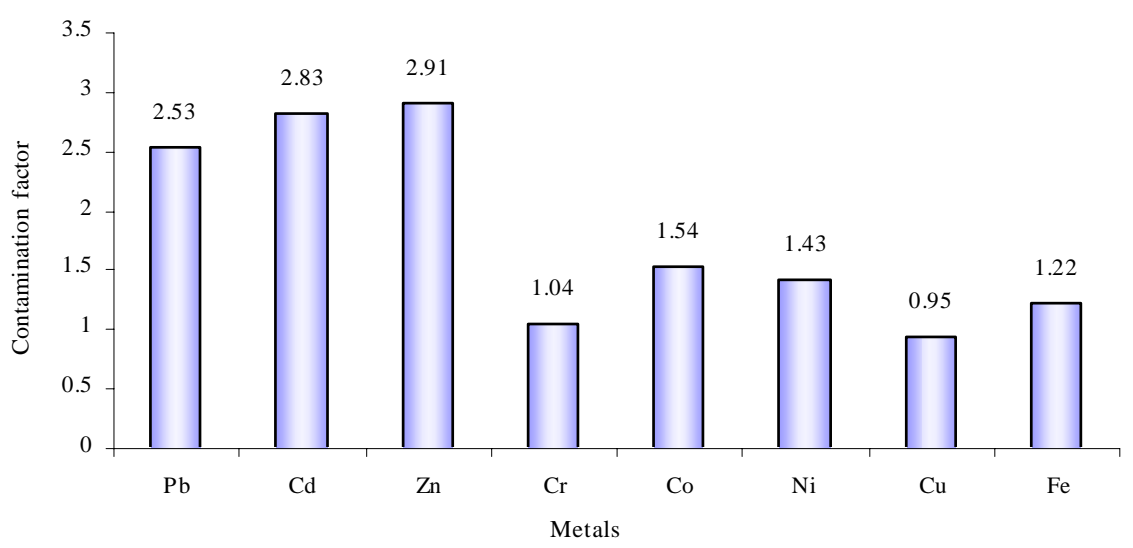

Fig. 4: Contamination factor of each metal in soil samples

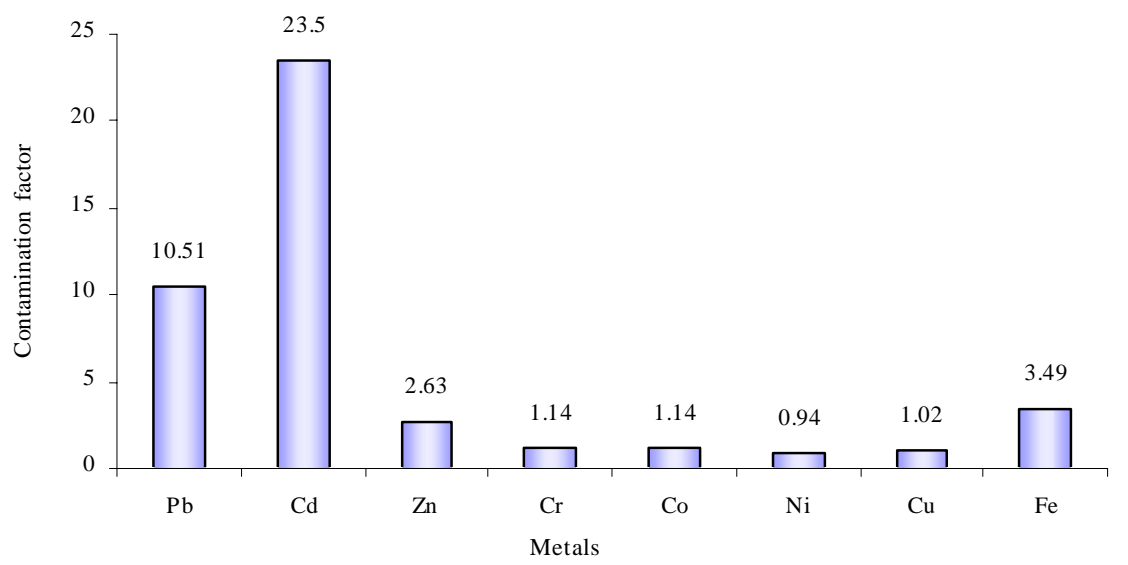

Fig. 5: Contamination factor of each metal in plant samples

Table 3: Enrichment factor of metals in plant per sampling point

\begin{tabular}{lcccccccc}
\hline Site & $\mathrm{Pb}$ & $\mathrm{Cd}$ & $\mathrm{Zn}$ & $\mathrm{Cr}$ & $\mathrm{Co}$ & $\mathrm{Ni}$ & $\mathrm{Cu}$ \\
\hline $\mathrm{B}$ & 3.03 & 3.03 & 0.44 & 0.25 & 0.27 & 0.19 & 0.23 & 1.06 \\
$\mathrm{C}$ & 6.14 & 8.19 & 1.25 & 0.68 & 0.68 & 0.55 & 0.55 \\
$\mathrm{D}$ & 3.13 & 6.80 & 1.14 & 0.35 & 0.43 & 0.40 & 0.38 \\
$\mathrm{E}$ & 1.78 & 9.71 & 0.64 & 0.26 & 0.19 & 0.17 & 1.80 \\
Mean & 3.52 & 6.93 & 0.87 & 0.39 & 0.39 & 0.33 & 0.21 & 1.85 \\
\hline
\end{tabular}

Table 4: Correlation coefficient of metals in soil with metals in plants

\begin{tabular}{lcc}
\hline Metals in soil & Correlation coefficient & Metals in plant \\
\hline $\mathrm{Pb}$ & 0.48 & $\mathrm{~Pb}$ \\
$\mathrm{Cd}$ & 0.96 & $\mathrm{Cd}$ \\
$\mathrm{Zn}$ & 0.56 & $\mathrm{Zn}$ \\
$\mathrm{Cr}$ & 0.41 & $\mathrm{Cr}$ \\
$\mathrm{Co}$ & 0.58 & $\mathrm{Co}$ \\
$\mathrm{Ni}$ & -0.58 & $\mathrm{Ni}$ \\
$\mathrm{Cu}$ & -0.71 & $\mathrm{Cu}$ \\
$\mathrm{Fe}$ & 0.89 & $\mathrm{Fe}$ \\
\hline
\end{tabular}

\section{CONCLUSION}

Metal pollutions caused by solid wastes disposal have been found to be more significant than that from traffic or vehicular activities. C. odorata has been identified to have potential to accumulate heavy metals, particularly $\mathrm{Pb}$ and $\mathrm{Cd}$, which are toxic to the ecosystem. It can be used as a biomarker for heavy metal pollution and a bioremediation agent. The need to further study on the role of atmospheric precipitation and seasonal variation on this ability of $C$. odorata is envisage. 


\section{REFERENCES}

Binggeli, P., (1997). Chromolaena odorata (L.) King and Robinson (Asteraceae) Eupatorium odoratum L., Available from: http://www.members.lycos.co.uk/WoodyPlantEcology/ docs/web-sp4.html.

Bulut, Y.; Baysal, Z., (2006). Removal of Pb(II) from wastewater using wheat bran. J. Environ. Manage., 78 (2), 107-113 (7 pages).

Cabrera, G.; Perez, R.; Gomez, J. M.; Abalos, A.; Cantero D., (2006). Toxic effects of dissolved heavy metals on Desulfovibrio vulgaris and Desulfovibrio sp. strains. J. Hazard. Mater., 135 (1-3), 40-46 (7 pages).

Cao, Z. H.; Hu, Z. Y., (2000). Copper contamination in paddy soils irrigated with wastewater. Chemosphere, 41 (1-2), 3-6 (4 pages).

Conacher, H. B.; Page, B. D.; Ryan, J. J., (1993). Industrial chemical contamination of foods (Review). Food Addit. Contam., 10 (1), 129-143 (15 pages).

Cruttwell McFadyen, R. E., (1988). Ecology of chromolaena odorata in the neotropics. Muniappan, R. (Ed.). Proceeding of the $1^{\text {st. }}$ International Workshop on biological control of Chromolaena odorata, 13-20. Bangkok.

Cruttwell McFadyen, R. E.; Skarrat, B., (1996). Potential distribution of Chromolaena odorata (siam weed) in Australia, Africa and Oceania. Agric. Ecosyst. Environ., 59 (1-2), 8996 (8 pages).

Cui, Y. J.; Zhu, Y. G., Zhai, R. H.; Chen, D. Y.; Huang, Y. Z.; Qui, Y., (2004). Transfer of metals from soil to vegetables in an area near a smelter in Nanning, China. Environ. Int., 30 (6), 785-791 (7 pages).

Donalson, W. E., (1980). Trace element toxicity, In: introduction to biochemical toxicology, Ernest Hodgson and Frank E. Guthrie Eds., Elsevier, New York, 330-340.

Dunnett, C. W., (1955). A multiple comparison procedure for comparing several treatments with a control. J. Amer. Stat. Assoc., 50, 1096-1121 (25 pages).

Fang, T. H.; Hwang, J. S.; Hsiao, S. H.; Chen, H. Y., (2006). Trace metals in seawater and copepods in the ocean outfall area off the northern Taiwan coast. Marine Environ. Res. 61 (2), 224-243 (20 pages).

Farkas, A.; Salanki, J.; Specziar, A., (2002). Relation between growth and the heavy metal concentration in organs of bream Abramis brama L. populating lake Balaton. Arch. Environ. Contam. Toxicol., 43 (2), 236-243 (8 pages).

Farombi, E. O.; Adelowo, O. A.; Ajimoko, Y. R., (2007). Biomarkers of oxidative stress and heavy metal levels as indicators of environmental pollution in African Cat fish (Clarias gariepinus) from Nigeria Ogun river. Int. J. Environ. Res. Public Health., 4 (2), 158-165 (8 pages).

Gardea-Torresdey, J. L.; Tiemann, K. J.; Gonzalez, J. H.; Rodriguez, O., (1997). Phytofiltration of hazardous metal ions by alfalfa: A study of calcium and magnesium interferences. J. Hazard. Mater., 56 (1-2), 169-179 (11 pages).

Gautier, L., (1993). Reproduction of pantropical weed: Chromolaena odorata (L.). Candollea, 48, 179-193 (15 pages).

Gillis, P. L.; Dixon, G.; Borgmann, U.; Reynoldson, T. B., (2004). Uptake and depuration of cadmium, nickel and lead in laboratory-exposed Tubifex tubifex and corresponding changes in the concentration of a metallothionein-like protein. Environ. Toxic. Chem., 23 (1), 76-85 (10 pages).
Gonzalez, R. C.; Gonza'lez-Cha'vez, M. C. A., (2006). Metal accumulation in wild plants surrounding mining wastes. Environ. Pollut., 144 (1), 84-92 (9 pages).

Gothberg, A.; Greger, M.; Holm, K.; Bengtsson, B. E., (2004). Heavy metals in the environment influence of nutrient levels on uptake and effects of mercury, cadmium and lead in water spinach. J. Environ. Qual., 33, 1247-1255 (9 pages).

Hakanson, L., (1980). An ecological risk index for aquatic pollution control A sedimentological approach. Water Res., 14 (8), 975-1001 (76 pages).

Hammaini, A.; Gonzalez, F.; Ballester, A.; Bla'zquez, M. L.; Munoz, J. A., (2006). Biosorption of heavy metals by activated sludge and their desorption characteristics. J. Environ. Manag., 84 (4), 419-426 (8 pages).

Ivens, G. W., (1974). The problem of Eupatorium odoratum L. in Nigeria. PANS 20: 76-82 (7 pages).

Laflamme, I. S.; Couillard, Y.; Campbell, P. G.; Hontela, A.; (2000). Interrenal metallothionein and cortisol secretion in relation to $\mathrm{Cd}, \mathrm{Cu}$ and $\mathrm{Zn}$ exposure in yellow perch, Perca flavescens, from Abitibi lakes. Can. J. Fish. Aquat. Sci. 57, 1692-1700 (9 pages).

Liu, W.; Zhao, J.; Ouyang, Z.; Soderlund L.; Liu, G., (2005). Impacts of sewage irrigation on heavy metal distribution and contamination in Beijing, China. Environ. Int., 31, 805-812 (8 pages).

Low, K. S.; Lee, G. K.; Liew, S. C., (2000). Sorption of cadmium and lead from aqueous solutions by spent grain. Proc. Biochem., 36 (1), 59-64 (6 pages).

Madejon, P.; Murillo, J. M.; Maranon, T.; Espinar, J. L.; Cabrera, F., (2006). Accumulation of As, Cd and selected trace elements in tubers of Scirpus maritimus L. from Donana marshes (South Spain). Chemosphere, 64 (5), 742-748 (7 pages).

Manahan, S. E., (1992). Toxicological chemistry $2^{\text {nd. }}$ Eds, Lewis Publisher Inc., Chelsea, Michigan, USA, 1-52 (52 pages).

Perceval, O.; Pinel-Alloul, B.; Methot, G.; Couillard, Y.; Giguere, A.; Campbell, P. G. C.; Hare, L., (2002). Cadmium accumulation and metallothionein synthesis in freshwater bivalves (Pyganodon grandis): relative influence of the metal exposure gradient versus limnological variability. Environ. Pollut., 118 (1), 5-17 (13 pages).

Quevauviller, P.; Lavigne, R.; Cortez, L., (1989). Impact of industrial and marine wastes on the heavy metal distribution in the drainage basin and estuary of the Sado River (Portugal). Environ. Pollut., 59 (4), 267-286 (20 pages).

Reinmann, C.; Siewers, U.; Tarvaunen, T.; Bityukova, L.; Eriksson, J.; Gilucis, A., (2000). Baltic soil survey: Total concentrations of major and selected elements in arable soils from 10 countries around the Baltic Sea. Sci. Total Environ., 257 (2-3), 5084-5091 (8 pages).

Schiff, K. C.; Weisberg, S. B., (1999). Iron as a reference elements for determining trace metals enrichment in southern California coastal self sediments. Mar. Environ. Res., 48 (2), 161-176 (16 pages).

Sheng, D. H.; Zhou, Q. X.; Li, P.; J., (2001). Pollution ecology. Beijing Science Press. 284.

Tomlison, L.; Wilson, G.; Harris, R.; Jeffrey, D. W., (1980). Problems in the assessments of heavy-metal levels in estuaries and formation of a pollution index. Helgol Meeresunters, 33 (1-4), 566-575 (10 pages). 
Tsui, M. T. K.; Cheung, K. C.; Tam, N. F. Y.; Wong, M. H., (2006). A comparative study on metal sorption by brown seaweed. Chemosphere, 65 (1), 51-57 (7 pages).

Velez, D.; Montoro, R., (1998). Arsenic speciation in manufactured seafood products: A review. J. food. Protect., 61 (9), 1240-1245 (6 pages).

Vutukuru, S. S., (2005). Acute effects of hexavalent chromium on survival, oxygen consumption, hematological parameters and some biochemical profiles of the Indian Major carp, Labeo rohita. Int. J. Environ. Res. Public Health., 2 (3), 456-462 (7 pages).
Wang, Y. G., (2001). Non-pollution vegetable productive theory and practice. China's Agricultural Publishing House. 47.

Wang, X. C.; Yan, W. D.; An, Z.; Lu, Q.; Shi, W. M.; Cao, Z. H.; Wong, M. H., (2003). Status of trace elements in paddy soil and sediment in Taihu Lake region. Chemosphere, 50, 707-710 (4 pages).

Waqar, A., (2006). Levels of selected heavy metals in Tuna fish. Arab. J. Sci. Eng., 31 (1 A), 89-92 (4 pages).

\section{AUTHOR (S) BIOSKETCHES}

Agunbiade, F. O., B.Sc., M.Sc., Lecturer, Department of Chemical Sciences, College of Natural and Applied Science, Bells University of Technology, Ota, Nigeria and a Ph.D. research student in industrial and environmental chemistry at University of Ibadan, Nigeria. Email: foagunbiade@gmail.com

Fawale, A. T., B.Sc., M.Sc. in biochemistry was a research supervisor at International Institute of Tropical Agriculture, Ibadan and presently is a production operator with Chevron Nigeria Ltd., Chevron Nigeria/Mid-Africa SBU. Email: adewalefawale@chevron.com 